UDC $1: 316.3+340.12$

DOI: https://doi.org/10.21564/2075-7190.38.139943

Manuilov Eugene Mykolayovych, Doctor of Philosophy, Professor, professor at Philosophy Department of Yaroslav Mudryi

National Law University, Kharkiv

e-mail: manuilov1946@gmail.com

ORCID ID: 0000-0002-3896-6017;

Kalynovsky Yuri Yuriyovych, DSc in Philosophy, Professor, professor at Philosophy Department of Yaroslav Mudryi

National Law University, Kharkiv

e-mail: kalina_uu@ukr.net

ORCID ID: 0000-0002-0081-8107

\title{
LEGAL COMMUNICATION AS A FACTOR OF NATIONAL STATE BUILDING
}

Major properties and functions of legal communication were analyzed. The specifics of the legal communication impact of legal communication on state building processes were identified. Correlation of the legal communication development and the evolution of democratic legal awareness and legal culture in modern Ukraine were described. Basic models of communication in the civil society and power interaction were considered. It was proven that it was the dialogue model of legal communication that optimally meets the objectives of the democratic state building.

Keywords: communication, legal communication, state building, legal culture, models of legal communication.

Problem setting. State building democratic process is ensured by both horizontal and vertical interactions in a specific social field. In turn, various social communications are the mechanism that enables to reproduce the values of democratic discourse while developing the state. Social communications include legal communication, which is established between subjects in a legally stipulated way and according to the existing social legal traditions. The topicality of the problem of the efficient legal communication functioning is predetermined, for the domestic state building, by the need of tighter interaction between the society and authorities, the objectives of developing the rule of law and legal society, the importance of developing democratic legal culture and legal awareness etc.

Recent research and publications analysis. The phenomenon of legal communication and its role in public and state building processes have been studied 
from different theoretical and methodological perspectives, which has been evidenced in the conceptual works by D. Andreyev, A. Bortnyak, A. Polyakov, I. Sytar, A. Tokarska etc. A number of researchers focused on the specific aspects of the above problem. For instance, O. Bukhtaty analyzed the communicative function of the modern democratic state, while N. Onishchenko - civil society building, considering the communicative-legal factor. For this research work the reasons described by O. Makeyeva as to the definition of the concept and content of the legal communication in the contemporary information environment development, as well as the results of the study conveyed by Yu. Koval on the basic aspects of communicative philosophy of J. Habermas, appeared important to identify the criteria of the state power effectiveness.

Paper objective. The paper aims at specifying the essential features of legal communication and identifying its impact on the national state building process.

Paper main body. According to the experts, legal communication is a kind of social communication based on legal norms, the procedure of subjects' interaction, which is aimed at meeting their lawful interests and needs in exchanging legal and other information [1, p. 11].

A. Bortnyak believes that legal communication implies the signs of transfer and perception (their understanding). In this case, law will be a kind of functional discourse, whereas legal behavior will be reflexive to what was perceived. Therefore, legal communication is an underlying principle of social subject legal organization, which is in place owing to the use of certain signs and sign patterns. This way legal behavior is an instrumental substantive activity, regulated by established rules [2, p. 182].

Accordingly, the specifics of perceiving legal signs, symbols, values and traditions by the subjects of state building directly determine qualitative indicators of the state development. This interdependence is due to the fact that state building as an objective phenomenon also has a subjective element - understanding (interpretation) by politicians and civil servants of the legal ideal, legal norms and values, which determines the content of their activities, their performance of functions and duties.

A. Tokarska argues that interpretation of law as a means of communication is a step towards contemporary rational legal relations. Norms must not be voluntarily introduced into public life, and vice versa, they have to be found in the context of the latter as the interaction of the optimal subject-subject interaction. In other words, these norms will confirm their public and existential irrelevance and will not be enforced de facto. Thus, the rule of law becomes enforceable only as a subsystem of the legal society, which is impossible in the conditions of polarization of the letter and spirit of the law, and, therefore, it is to be a self-organized system seeking a communicative balance, mutual responsibility and equality [3, p. 35]. 
It may be affirmed that the law will be efficient as the means of communication only provided its content meets the needs of society and state, the legal norm itself is perceived by public opinion as just, and the norm will be irreversible. It is evident that the effective channels of legal communication are the basis for strengthening the activity of state bodies and civil society organizations, which will eventually encourage the development of democratic grounds for the national domestic state building. Legal communication as a factor of state building must be based not only on the developed legislation, but also rely on certain procedures, indicated in the valid legal norms and cultural traditions. Legal communication combines institutional and non-institutional elements. The process of developing a democratic state in Ukraine involves the establishment of its own forms, means, traditions and rules of legal communication.

Analyzing the specifics of communication between the authorities and society as well as summarizing a number of studies, D. Andreyev offers to describe the process using a number of models and indicating that each existing communication model has its ways of organizing a message and information signal distribution. The first reporting model provides for the centralized information distribution. The second is a registration model of transmitting information signal, which is opposite to the reporting model. This communication model implies that the center requests recipients and receives a response from a peripheral source to summarize information. It is used when the access is not allowed to the information center. The third model is a dialog one, which involves real communication and whose theme is agreed by the parties. Information exchange, during which the number of participants increases and there appears a moderator, leads to the dialog model turning into the reporting one. The author considers the dialog model to be the most effective since the communication knowingly takes into account recipient's ideas. The fourth is a distance model. It is typical of the situations when the person requesting for information is in the periphery of the communication line and seeks necessary data in the data storage center (server). The theme is identified by the user, not by the center. This is the so-called consultancy service similar to the operations with public call centers, service and information centers [4, p. 53-54].

It is definitely vital to identify which legal communication model is basic in the system of interaction between the state and an individual and the civil society. To our mind, the nature and essence of the democratic state building is the closest to the dialog model, which provides for the equality of the communication subjects, identification of discussion points based on the consensus. From the viewpoint of communicative philosophy, the rules of law find reflexive grounds in real practical communication, which is of procedural nature. However, this discourse must correlate with ideal communication (the analog of natural law), which, as a regulatory idea, means the direction of the rational reasons of norms and is the criterion 
of establishing the «true consensus». According to K.-O. Apel and J. Habermas, just decisions are reasonable and based on discourse ethics positions. Argumentative discourse as the highest instance of public life is the condition for making all reasonable decisions. This discourse becomes possible provided the essential procedural normative rights and the general responsibility are complied with by all potential partners in the discourse, which is a transcendent pragmatic correlate of the idea of human rights (natural law) [5, p. 97].

According to O. Bukhtaty, the main objective of the state policy in public communications must be to identify the ways of legal response to the issue of ensuring efficient communicative interaction between governmental authorities, local authorities and the public, mass media, exercising the power directly and via the governmental bodies, which encourages and strengthens democracy, builds civil society, and integrates Ukraine into the European community [6, p. 82].

Therefore, legal communication is characterized by the sequence of actions, specified by the respective legal means (means-actions and means-determinations) that are of dispositive and imperative nature. Legal communication consists of the elements, has a complex structure and requires stability of connections, which enables to keep its integrity under internal and external changes [7, p. 122].

Apparently, legal communication encourages the establishment of instrumental and value-based role of law in state building, which is especially important for new democracies, including Ukraine. The channels of legal communication are primarily the «bearers» of specific values required to establish constants in the public and state existence as well as the procedures of legal state and law-governed society, democratic standards of legal culture and awareness.

In turn, the communicative function of law guarantee that the parties of legal relations receive information on the position of the state regarding the necessary, allowed or prohibited behavior. Social life of individuals is organically related to receiving, perceiving, acquiring and using this information. Legal information is a kind of social data. The main aim of the law is to ensure agreement, civil peace in the society from the human rights perspective. If in the society (namely in the modern Ukrainian society) there appear ideas that do not meet universal human values, moral, human rights, then their role and significance inevitably devaluate. Human history has sufficient evidence that any society can prosper and develop at its best only relying on the ideas of the legal, just life organization, where the rule of law is recognized [8, p. 95].

It is common knowledge that in the legal state, legal values must be implemented in the legal relations and they are to determine anthropocentric sense of law. Owing to the legal values, the person assesses all his or her legal reality and also makes the choice according to the positive legal responsibility. The aim of legal values is to integrate human objectives and interests with state interests and 
objectives. These social values, including moral, cultural, religious, common human ones, become legal only when they are recorded in the legal norm. It is due to this rule of law that values become legal. Legal norms provide conditions for their implementation and act as a means to achieve them [9, p. 28].

Nonetheless, some legal values become the grounds for legal communication only provided they are perceived by the public (individual) legal awareness and do not contradict established norms of legal culture, while their meanings are respectively understood by the subjects of legal relations. Following the above logic, P. Polishchuk notes that there is a need of the conscious acquisition of legal values by citizens. Understanding and respecting them lead to realizing the importance of law, its role in public relations. Legal values are specific social legal phenomena, legal means and mechanisms. They include: specific manifestation of the law own value in the human practical life (guarantee of rights, freedoms, equality and justice); fundamental, natural human rights, main democratic principles; specific legal means and legal mechanisms (what is called legal tools), which ensure the value of law; institutions, which express the optimal correlation between the normative and individual regulation etc. [10, p. 80].

It is obvious that legal communication in a democratic state progresses in case the level of legal awareness and culture of the social interaction subjects rises. This regularity is determined by the fact that there is a growing demand for legal information, belief in the enforceability and necessity of the legal norm itself. In turn, the development of interactive channels of legal communication and the effectiveness of their functioning in the social environment promote the growth of democratic awareness and legal culture.

O. Babkin points out that legal culture is an extremely sophisticated phenomenon in terms of its internal structure and the abundance of social connections. It is not limited to the knowledge of laws, norms of law, though it may be a compulsory pre-condition. Legal culture includes not only legal awareness but also the level of legal activity for ensuring and strengthening the rule of law, human rights and freedoms [11, p. 7].

The main features of sufficient (or high) level of legal culture are: routine implementation of the rule of law principles in public and state life as well as the reliable condition of the legal protection and the protection of key human and civil rights and freedoms; the knowledge and understanding by citizens of legal norms and orders, respect to law as the main value of the society; compliance with essential valid national laws and norms by most citizens, the ability to apply legal knowledge, implement and protect their subjective rights and legal interests, perform legal duties; lawful behavior of the population in different areas of public life; active civic position as to the prevention of law breaking and identifying civil integrity in the protection of human rights; objective law-enforcement work, in particular, that of law-enforcement and human rights bodies; sufficient (high) level of the develop- 
ment of public law science, involving researchers from different fields in the development of the regulation drafts etc. [12, p. 14].

Thus, legal communication is the process of interaction between its subjects based on the rules of behavior, reflected in regulations and other legal sources, by exercising their rights and performing their duties to find a compromise and mutual understanding. Its features are given below:

1) legal communication emerges between equal subjects on the micro-level (between the subjects of law) and macro-level (between individuals and the legal system on the whole);

2) subjects of legal communication select the ways of behavior during their interaction;

3 ) the importance level of legal culture of the subject of legal communication for legal communication;

4) in legal communication subjects act as the carriers of subject's rights and legal duties;

5) legal communication is objectivized in the regulatory texts;

6) the main purpose of legal communication is to reach consensus among the subjects and reach understanding among them [13, p. 39].

Legal communication in the democratic state must encourage the establishment of justice and effective power activities, while the very channels of communication must be open for volunteers to participate in the discussion of socially important issues.

When analyzing the above problem, Ukrainian scholar Yu. Koval argues that the power communicative effectiveness criteria should include the concept of $m u$ tual understanding offered by J. Habermas. The above category is significant since it acts as a polysemantic aspect of recognizing certain limits in the areas of life world and system as the interference, and the interaction, which, according to J. Habermas, must be carried out according to the principles below:

- clearness of state body messages (meaning that the authorities themselves must initiate «a social dialog with public, offer specific vectors in the society development with no state interference with the private sector»);

- validity of knowledge (meaning the competence of the state bodies in solving burning social issues and in selecting political vectors);

- reliability of intentions (meaning power focus on the strict compliance with the declared policy or election promises, it is at this level that it is worth clarifying to the citizens the reasons and restrictions of adjusting the declarative level according to the publicly clear and understandable arguments);

- correctness of actions (it is to be noted that the criterion of correctness is one of the most complex and disputable concepts in the communicative approach offered by J. Habermas since the correctness of actions, to his mind, is a certain level of discursive policy, that is the preference is given not to the content of the 
authorities' activities but to the reaction of the society and the content of the message, which is strengthened by the state bodies) [14, p. 59].

Conclusions of the research. It may be stated that a multi-channel and layered legal communication is one of the essential features of the modern democratic political legal system. Legal communication becomes actionable as long as the state can institutionally and normatively ensure its transparency, and the citizens, in turn, actively use its channels considering them an effective way of their communication with the state bodies. Legal communication provides control of the civil society over the authorities' activities and the articulation of its interests in public space. It also meets the need of the citizens to receive prompt and reliable information. An important condition for the development of legal communication is democratization of the citizens' legal culture and awareness. The abovementioned processes dialectically interact and determine the existence of one another, creating significant bases to establish a democratic, legal state in modern Ukraine.

\section{ЛIТЕРАТУРА}

1. Поляков А. В. Общая теория права: проблемы интерпретации в контексте коммуникативного подхода: курс лекций. Санкт-Петербург: Изд. дом С.-Петерб. гос. ун-та, 2004. 864 с.

2. Бортняк А. Ф. Правова комунікація як спосіб функціонування правових знаків. Наше право. 2014. №3. С. 177-183.

3. Токарська А. С. Комунікативна природа права і правової комунікації. Філософські та методологічні проблеми права. 2011. № 1. С. 32-39.

4. Андрєєв Д. В. Комунікація як складова системи суспільно-правових відносин влади та суспільства. Науковий вісник Національної академії внутрішніх справ. 2013. № 1. С. 51-55.

5. Чернушенко Д. А. Толерантність як світоглядна основа правосвідомості в умовах інформаційного суспільства. Філософські та методологічні проблеми права. 2013. № 1-2. С. 94-103.

6. Бухтатий О. Є. Концептуальні основи комунікаційної функції сучасної демократичної держави. Інформащійне суспільство. 2016. Вип. 23. С. 77-84.

7. Ситар I. М. Комунікація у праві: до проблеми міжкультурної комунікації. Вісник Наиіонального університету «Львівська політехніка». Юридичні науки. 2014. № 807. C. 119-123.

8. Оніщенко Н. Формування громадянського суспільства: комунікативно-правовий чинник. Вісник Конституційного Суду Украӥни. 2015. №5. С. 88-96.

9. Соломчак Х. Б. Соціальні та правові цінності як детермінанти позитивної правової відповідальності. Наме право. 2014. № 1. С. 27-34.

10. Поліщук П. В. Поняття правових цінностей та методологічні підходи до розуміння їх сутності. Філософські та методологічні проблеми права. 2013. № 1-2. С. 75-81. 
11. Бабкіна О. В. Політико-правова культура демократичного типу: проблеми формування. Науковий часопис НПУ імені М. П. Драгоманова. Серія 22: Політичні науки та методика викладання соиіально-політичних дисциплін. 2011. Вип. 5. С. 5-10.

12. Огаренко Т. О. Політична та правова культура як чинник демократизації суспільства. Право та державне управління. 2013. № 1. С. 13-17.

13. Макеєва О. М. Поняття і сутність правової комунікації в сучасному інформаційному просторі. Юридичний вісник. 2017. № 3 (44). С. 35-41.

14. Коваль Ю. О. Комунікативний підхід Юргена Габермаса як критерій ефективності державної влади. Вісник СевНТУ. Серія: Політологія. 2013. Вип. 145. C. $58-62$.

\section{REFERENCES}

1. Poljakov, A. V. (2004). Obshhaja teorija prava: problemy interpretacii v kontekste kommunikativnogo podhoda: kurs lekcij. SPB.: Izd. dom S.-Peterb. gos. un-ta. [in Russian].

2. Bortniak, A. F. (2014). Pravova komunikatsiia yak sposib funktsionuvannia pravovykh znakiv. Nashe Pravo - Our right, 3, 177-183 [in Ukrainian].

3. Tokarska, A. S. (2011). Komunikatyvna pryroda prava i pravovoi komunikatsii. Filosofski ta metodolohichni problemy prava - Philosophical and methodological problems of law, 1, 32-39 [in Ukrainian].

4. Andrieiev, D. V. (2013). Komunikatsiia yak skladova systemy suspilno-pravovykh vidnosyn vlady ta suspilstva. Naukovyi visnyk Natsionalnoi akademii vnutrishnikh sprav - Scientific Bulletin of the National Academy of Internal Affairs, 1, 51-55 [in Ukrainian].

5. Chernushenko, D. A. (2013). Tolerantnist yak svitohliadna osnova pravosvidomosti $\mathrm{v}$ umovakh informatsiinoho suspilstva. Filosofski ta metodolohichni problemy pravaPhilosophical and methodological problems of law, 1-2, 94-103 [in Ukrainian].

6. Bukhtatyi, O. YE. (2016). Kontseptualni osnovy komunikatsiinoi funktsii suchasnoi demokratychnoi derzhavy. Informatsiine suspilstvo - Information society, issue 23, 77-84 [in Ukrainian].

7. Sytar, I. M. (2014). Komunikatsiia u pravi: do problemy mizhkulturnoi komunikatsii. Visnyk natsionalnoho universytetu "lvivska politekhnika". Yurydychni nauky-Bulletin of the National University "Lviv Polytechnic». Law Sciences, 807, 119-123 [in Ukrainian].

8. Onishchenko, N. (2015). Formuvannia hromadianskoho suspilstva: komunikatyvnopravovyi chynnyk. Visnyk konstytutsiinoho sudu ukrainy - Bulletin of the Constitutional Court of Ukraine, 5, 88-96 [in Ukrainian].

9. Solomchak, KH. B. (2014). Sotsialni ta pravovi tsinnosti yak determinanty pozytyvnoi pravovoi vidpovidalnosti. Nashe pravo - Our right, 1, 27-34 [in Ukrainian].

10. Polishchuk, P. V. (2013). Poniattia pravovykh tsinnostei ta metodolohichni pidkhody do rozuminnia yikh sutnosti. Filosofski ta metodolohichni problemy prava Philosophical and methodological problems of law, 1-2, 75-81 [in Ukrainian]. 
11. Babkina, O. V. (2011). Polityko-pravova kultura demokratychnoho typu: problemy formuvannia. Naukovyi chasopys NPU imeni M. P. Drahomanova. Seriia 22 : Politychni nauky ta metodyka vykladannia sotsialno-politychnykh dystsyplin - Scientific journal of NPDU. Series 22: Political Sciences and Methods of Teaching Socio-Political Disciplines, issue 5, 5-10 [in Ukrainian].

12. Oharenko, T. O. (2013). Politychna ta pravova kultura yak chynnyk demokratyzatsii suspilstva. Pravo ta derzhavne upravlinnia - Law and public administration, 1, 13-17 [in Ukrainian].

13. Makeieva, O. M. (2017). Poniattia i sutnist pravovoi komunikatsii v suchasnomu informatsiinomu prostori. Yurydychnyi visnyk - Law Bulletin, 3 (44), 35-41 [in Ukrainian].

14. Koval, YU. O. (2013). Komunikatyvnyi pidkhid yurhena habermasa yak kryterii efektyvnosti derzhavnoi vlady. Visnyk SevNTU. Ser. : Politolohiia - Bulletin of SevSU. Ser. : Politology, issue 145, 58-62 [in Ukrainian].

Мануйлов Свген Миколайович, доктор філософії, професор кафедри філософії Національного юридичного університету імені Ярослава Мудрого, м. Харків, Україна;

Калиновський Юрій Юрійович, доктор філософських наук, професор кафедри філософії Національного юридичного університету імені Ярослава Мудрого, м. Харків, Україна

\section{ПРАВОВА КОМУНІКАЦІЯ ЯК ЧИННИК ВІТЧИЗНЯНОГО ДЕРЖАВОТВОРЕННЯ}

Постановка проблеми. Державотворчий прочес демократичного спрямування забезпечується як горизонтальними, так і вертикальними взаємодіями у певному соціальному просторі. В свою чергу різноманітні соціальні комунікачії є тим механізмом, який дозволяє відтворювати иінності демократичного дискурсу під час розбудови держсави. Різновидом соиіальних комунікаиій є правова комунікація, яка встановлюється між суб'єктами у законодавчо визначений спосіб та згідно з існуючими у суспільстві правовими традиціями.

Аналіз останніх досліджень і публікацій. Феномен правової комунікації та ї̈ роль у суспільних й державотворчих процесах досліджуються науковиями з різних теоретико-методологічних позицій, що знайшло своє відображення у конщептуальних роботах Д. Андрєєва, А. Бортняка, А. Полякова, I. Ситар, А. Токарської та ін.

Мета намого дослідження полягає у виявленні сутнісних рис правової комунікаиії та визначенні особливостей ї̈ впливу на вітчизняний держсавотворчий процес.

Виклад основного матеріалу. Стверджується, що право являтиме собою дієвий засіб комунікаиії лише у тому випадку, коли його зміст буде відповідати потребам суспільства та держави, сама правова норма ідентифікуватиметься суспільною 
свідомістю як справедлива, а дія иієї норми матиме невідворотний характер. Ефективні канали правової комунікації є підгрунтям для зміцнення діяльності як державних органів, так і структур громадянського суспільства, що у підсумку сприятиме розвитку демократичних засад вітчизняного держсавотворення. Правова комунікаиія як чинник розбудови держави має базуватися не тільки на розвиненому законодавстві, а й спиратися на певні процедури, щь відображені у чинних правових нормах і культурних традиціях.

Доведено, щзо правова комунікаиія сприяс утвердженню інструментальної та иіннісної ролі права у державотворчому прочесі, щзо особливо важливо для «молодих демократій», України зокрема. Канали правової комунікаџії є в першу чергу «провідниками» певних иінностей необхідних для утвердження у суспільно-державному бутті констант і процедур правової держави й правового суспільства.

Висновки. Правова комунікаиія забезпечує контроль громадянського суспільства за діями влади й артикуляцію його інтересів у публічному просторі, а також задовольняє потребу громадян у одержанні оперативної та правдивої інформачії. Важливою умовою розвитку правової комунікащії є демократизація правової культури та правосвідомості громадян.

Ключові слова: комунікачія, правова комунікачія, державотворення, правова культура, моделі правової комунікащії.

Мануйлов Евгений Николаевич, доктор философии, профессор кафедры философии Национального юридического университета имени Ярослава Мудрого, г. Харьков, Украина;

Калиновский Юрий Юрьевич, доктор философских наук, профессор кафедры философии Национального юридического университета имени Ярослава Мудрого, г. Харьков, Украина

\section{ПРАВОВАЯ КОММУНИКАЦИЯ КАК ФАКТОР ОТЕЧЕСТВЕННОГО ГОСУДАРСТВЕННОГО СТРОИТЕЛЬСТВА}

Проанализированы основные признаки и функиии правовой коммуникации. Определены особенности влияния правовой коммуникации на процессы государственного строительства. Показана коррелятивность развития правовой коммуникаиии и становления демократического правосознания и правовой культуры в современной Украине. Исследованы базовые модели коммуникаџии власти и гражданского общества. Доказано, что диалоговая модель правовой коммуникации в наибольшей мере соответствует задачам демократического государственного строительства.

Ключевые слова: коммуникачия, правовая коммуникачия, государственное строительство, правовая культура, модели правовой коммуникации.

\section{$\operatorname{son}$}

